\section{Complementary Medicine Research Practice| Methods| Perspectives}

Obituary - Nachruf

Complement Med Res 2018;25:292-293

DOI: $10.1159 / 000494076$
Published online: October 10, 2018

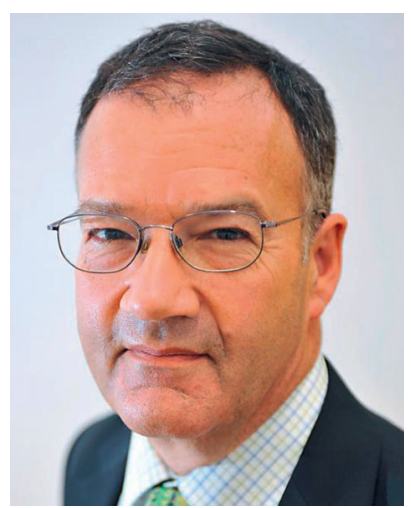

\title{
Dr. Peter Fisher - † August 15, 2018
}

I am fed up with writing obituaries. But life demands it. This obituary for Dr. Peter Fisher (September 2, 1950 - August 15, 2018) is at least as difficult as the one for George Lewith, who also died as unexpectedly. The tragic, even absurd, in this death are the day and the modality: On August 15, for Catholics, who Peter as a secular Jew was not, the feast day of Mary's Assumption, for English people the national 'cycle-to-work day' when people are encouraged to use their bike for going to work, he was thrown off his bike by a lorry in a left turn (in terms of Central European traffic this would be a right turn, i.e., nothing very spectacular) and died on the spot. For Peter, who left 2 adult children and had moved on into a new relationship, this cut the second phase of his life short.

Peter Fisher was the scientific director of the Royal London Hospital for Integrated Medicine, formerly the Royal London Homoeopathic Hospital, which is part of the University College London Hospital network. Apart from that, he was 1 of the 3 personal physicians to her Royal Majesty Queen Elizabeth II, and as such the representative of homeopathy in the royal household, which had always held homeopathy in high esteem. This was often the reason for ridicule directed against Peter and the royal family by sceptics. However, Peter was always quick in rebutting such attacks, as he was extremely well-read in all matters regarding research in homeopathy, in addition to his clinical experience as a practicing doctor. Peter Fisher was editor-in-chief of the journal 'Homeopathy', formerly the 'British Homoeopathic Journal', in print since 1911, and in this role he was in contact with the research scene worldwide. He was present at all relevant conferences, presenting political views on integrated medicine, including homeopathy, transferring them into a wider agenda of person-centred care that should focus on the whole patient, and scientific papers he was co-author of. Peter was not only active in administration, journal editing and politics, e.g., as the head of the WHO working group on homeopathy, but also in research having published a large number of papers.

A former graduate of Cambridge, with medical training from Westminster Hospital Medical School and specialization in rheumatology, he was extremely well-connected in all walks of science and life. He had published a seminal trial with a deceptively simple design: homeopathic Rhus toxicodendron C30 for patients with fibromyalgia who fitted the remedy picture of this therapy. Thereby, he laid the foundation for a simple, yet effective way of conducting trials on homeopathy by including only patients with a conventional diagnosis that also fitted preselected remedies. This idea spawned a fruitful series of studies by other authors and is still widely in use. But he was also active in various other forms of research: basic research with in-vitro models, for instance, and he had a huge interest in fundamental research. Although we both politely disagreed on potential working models - Peter favouring the 'memory' hypothesis, me advocating a non-local model - he was brave enough to publish my work anyhow, or perhaps he did so because he had received a fervently negative report by a homeopathic believer who said he should not publish my work, as it was dangerous for homeopathy. Peter disregarded the review and published it. Not many editors have the courage to go against reviewer advice these days. He did. In the scientific and in the public arena, Peter was present, with letters, interviews, articles. It is partly due to his incessant advocacy that homeopathy has not been completely wiped out by the anti-homeopathic climate of today's UK. For his merits, he was awarded the Albert Schweitzer Gold Medal by the Polish Academy of Medical Sciences already in 2007.

\section{KARGER}

(c) 2018 S. Karger GmbH, Freiburg

Fax +497614520714 
His advocacy for homeopathy was not due to stubbornness, it was based on personal and clinical experience, as well as on his take on the scientific literature. The newspaper report of the 'Evening Standard' on his death (www.standard.co.uk/news/london/doctor-to-the-queen-peter-fisher-killed-after-being-hit-by-lorry-whilecycling-in-holborn-a3912801.html) also contains a short video clip explaining how he came to become interested in complementary medicine. It was on a field trip in Asia when he saw a woman being operated on with just 3 acupuncture needles for anesthesia, something unheard of at the time in Western medicine. He quickly became interested and well-read, studied homeopathy and tried it out himself. His own research did the rest. When we met at conferences and workshops, several times he was suffering from a bout of flu or runny nose, and he was adamant that his bottle of Lycopodium $\mathrm{M}$ that he showed me, or whatever it was, kept him well and comparatively healthy.

I have known him primarily from those conferences and workshops. He was a brilliant presenter and orator, with quick wit, sharp arguments and a convincing rhetoric difficult to counter. He credited me once with the saying 'there is nothing more alive than a dead line'. I never said that, but I liked it and have used it ever since. He was a bastion against the sceptics community in the UK, time and again exposing flaws in arguments, neglect in presenting data, bias in selecting studies, and thus deconstructing the political agenda behind the supposedly scientific façade. He survived critique, attempts at overthrowing him. Rudeness he countered with a touch of ironic superiority. Only the wheels of a lorry he could not escape. What a painful loss.

I met Peter Fisher for the first time at the beginning of my own career, in 1984 or so, at a conference in London. He had invited David Reilly from Scotland, who was also starting to become active in research and presented the data from his study on Pollen C30 in allergic rhinitis. David became director of the Glasgow Homeopathic Hospital, which was later turned into the Hospital of Integrated Medicine. Now he runs his own consulting, charity and business devoted to promoting healing (www.thewelworld.org; TEDX Talk on healing: www.youtube.com/watch? $v=L U F g x k B P h 4 Y$ ). I asked David to write a few personal words. Here they are:

'To say Peter's death was a shock sounds like tired language, but there seems no better word - there was such impact, disbelief and sadness. I know so many of the thousands of people whose lives he touched will have felt this. For his loved one's pain, I have no words.

He deserves a better obituary than I can write. I can offer only a few personal reflections. I knew him from meetings, conferences, conversations and the like, but not in his clinical work or private life. Nor do I know sufficient details of his biography to do him any justice. However, I can attest that he was a man of great spirit, enormous commitment and impressive energy; his views were, well, hardly diffident, but they were always clear, confident and considered; he exuded enthusiasm; he always ran that extra mile with an athlete-like focus. Couple that with his persistent advocacy for homoeopathy and better medical care, plus his academic rigour sustained over decades, and you have his unique formula for the wide-ranging and truly exceptional impacts he has made - both directly and through catalysing others' contributions.

I remember when we were both heading up our seminal clinical trials in the 1980's - and when my work made the 'Lancet' he said, to my surprise, 'Ah, so you have won this first race'. I didn't know there was a race, but in time I would see that compared to him I was a mere sprinter with some achievements who then moved on to other fields after just 15 years. However, he outran me as a long distance runner in and across the fields of homeopathy into his fifth decade of contributions, lapping me, and just about all the rest of us, with ongoing achievements in research, editing, publishing, political dialogue and public discourse - to name just some of the races he was still running in right up until his death. That he took up cycling to work just in recent years, seems to speak of that evermoving spirit - and while I like everyone else who knew him felt an ironic sorrow at his early death in a cycling accident, I take some comfort from the fact he was active, on the go, until his last moment. I have a feeling that retirement would not have sat easily on his shoulders.

With his voice falling silent, this field has been diminished. As others step into this vacuum, they will not, cannot, replace his spark, but for sure they can draw on it for inspiration and honour the gifts he brought by calling from within themselves something of that determined animated long-distance commitment and creative drive he shared with us. Thank you, Peter.'

Harald Walach, Poznan, and David Reilly, Glasgow 